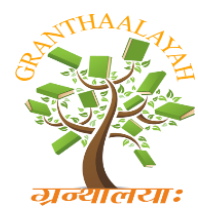

INTERNATIONAL JOURNAL OF RESEARCH GRANTHAALAYAH

A knowledge Repository

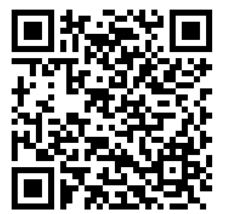

Science

\title{
SITE SELECTION ANALYSIS FOR SUITABLE AQUACULTURE FISH POND IN ANDONI L.G.A. RIVERS STATE, NIGERIA
}

\author{
Richard J. U. ${ }^{1}$, Dr. Chima Ogba ${ }^{2}$ \\ ${ }^{1}$ Department of Special Survey, Office of the Surveyor General, Moscow Road, Port Harcourt, \\ NIGERIA \\ ${ }^{2}$ MD. Geoid and Environmental Services, Limited, Rumuomasi, Portharcourt, NIGERIA
}

\begin{abstract}
The Andoni Rivers, Creeks, and Lagoon have been under stress due to over fishing which has led to the extinction of many fishes and other aquatic species. The extinction of fish has also led to the modification of fishing methods from the previously known methods such as cast net, drag net, hook and line etc to a more sophisticated method like the cover bush, and Oyima in the big Rivers. The shortage of fish in the Rivers has also discourage youths from engaging themselves in fishing rather they choose to involved in crude oil theft, arm robbery, and kidnapping that are anti-people. This study utilizes GIS software and remote sensing technology for aquaculture site selection analysis in Andoni LGA, Rivers State, Nigeria that will create direct and indirect employment opportunities to the men, women, and the youths thereby eradicating youth's restiveness in the area. The dataset used for the study are 2002 Landsat image, DEM data, and settlements point data. The software used is ArcGIS 10.1 for weighted over analysis and IDRISI TAIGA 16.0 for image classification. The three criteria (land use/ cover, DEM, settlement) were weighted in the weighted overlay tool with percentage of influence for lu/lc 40\%, DEM 20\%, and settlement 40\%. The suitability model for aquaculture ponds was produced with seven (7) classes from not suitable class value "o" to very highly suitable class with value "6". The very highly suitable class is made-up of 51 polygons with a total area of $278.1 \mathrm{Ha}$. this represents $1.0 \%$ of the total area (32928.4 Ha.), occurring more in the south and few in the northern map position along the Rivers. It was observed that the 51 polygons all have area that can support aquaculture ponds and also the location of it can support fresh and salt water ponds. The class o (not suitable) represents the water body in the study area covering an area of $8099.0 \mathrm{Ha}$. this represents $29.15 \%$ of the land area. It is not suitable because aquaculture cannot be sited in the water body since its serves as the food basket of the people. This study therefore justified that GIS and remote sensing integration can be used for aquaculture site selection because of the spatial components inherent in the criteria. The Local Government Authority should considered aquaculture programmes as key to the eradication of unemployment and youths restiveness through direct investment in the sector.
\end{abstract}




\section{Keywords:}

Aquaculture, DEM, Land use/ cover, Euclidean distance, Site selection, Suitability, Weighted overlay.

Cite This Article: Richard J. U., and Dr. Chima Ogba, "SITE SELECTION ANALYSIS FOR SUITABLE AQUACULTURE FISH POND IN ANDONI L.G.A. RIVERS STATE, NIGERIA" International Journal of Research - Granthaalayah, Vol. 4, No. 3 (2016): 219-232.

\section{INTRODUCTION}

One major productive and profit oriented sector in Nigeria after oil is aquaculture enterprise, which in return contributed immensely to the Gross Domestic Product of 4.4\% [1]. Fish is a highly nutritious and tasty aquatic species which are demanded by all parts of the world population particularly in developing countries [2]. Fish is rich in protein, amino acids, and source of vitamin B, Calcium, Phophorus, Iron, Copper, and Selenuim, and high content of Iodine in saltwater fish [2]. According to [3] reports fish accounts for 16.7 per cent of the global intake of animal protein and 6.5 per cent of all protein consumed. These important of fish for healthy diet have led to the alternative source of production called aquaculture (also called fish farming) to meet its demand. It is recorded that aquaculture and wild capture fisheries supplied the world with about 148 million tonnes of fish valued US\$217.5b [4]. At present, aquaculture accounts for 46 per cent of the total fish supply for human consumption [5]. Although, the production capacity varies from country to country this was based on the available technologies, specialities and management plans put in place. China, according to the 2013 reports produced $43.5 \mathrm{~m}$ tons of food fish and $13.5 \mathrm{~m}$ tons of aquatic algae thus making them the largest producer of aquaculture products in the world [3]. The other four countries that follow China in the rank are India, Viet Nam, Indonesia, and Bangladesh as revealed by the study. [5] listed major inland fish producer countries to include China, Bangladesh, India, Myanmer, Uganda, Cambodia, Nigeria, and Russian with Nigeria total production of 182.264 and 304.413tons between 2004 and 2008 respectively. Also, aquaculture in Nigeria has increase from 5 per cent to 20 per cent between 2001 and 2011 with an average growth rate of 13.5 per cent per annum [6], largely stimulated by improved technology and culture methods.

The Nigeria territory has a lot of water bodies that can support aquaculture especially the Niger Delta region which has many River networks which will provide suitable sites for aquaculture development. Fish farming being a profit yielding business has provided direct and indirect benefit to the population which is being realized in terms of generating thousands of employment opportunities, relatively low environmental impact [7], and enhanced socio-economic status of farmers [8].

Technological advancement has been introduced to effectively establish and manage aquaculture especially with the recent introduction of GIS and remote sensing technologies [9]. [10] pointed out that GIS is a potential powerful tool that assists decision-makers for selecting suitable sites for aquaculture development. This technology (GIS and Remote Sensing) has help decision makers in the formulation of policies regarding site selection, location, areal extent, topography, land use type, soil types, and market proximities of selected aquaculture. [10] also added that inherent spatial components of biophysical and socio-economic characteristics which vary from 
location to location aided aquaculture planning. The following researchers have introduced GIS and remote sensing in selecting suitable sites and management of aquaculture. [11] identified suitable land for Shrimp farming in Haiphong of Vietnam using GIS and remote sensing and discovered that 2604 ha. of land area are suitable for Shrimp farm. [12] Uses GIS and remote sensing data to analysed suitable site for production of pearl Oyster in China and it was observed that about 2.4 per cent of the total area has suitable classes. [13] study the suitable location of Prawn farm in Tully-Cardwell, north Queensland by using suitable elevation, proximity to water source, and distance from urban areas as criteria in selecting suitable site with results indicated that 12.76 per cent as suitable land area. [14] uses GIS and remote sensing data to study suitable site for aquaculture in Tuticorin coast, India. The dataset used include; IRS P6 LISS 3, Landsat ETM, MODIS, bathymetry sounding point, and electronic navigational chart and other parameters. Similarly, [15] apply GIS and remote sensing to examine suitable site for aquaculture in Pune - Maharashtra India and they observed that 0.25 per cent of the land area provides optimum site for its development. [16] analysed suitable site for soft-shell clam aquaculture in Newfoundland, Canada using GIS tools. [17] uses GIS to select aquaculture site in Margarita Island, Venezuela using base map of the area and 20 variables as criteria and the results indicated that 137 sites were ranked $75-70$ per cent suitable for the cultivation of mangrove Oyster. [18] in their work uses multi-criteria approach to determined suitable site for Perna Canaliculus Mussels in the Bay of Plenty, New Zealand. [19] applied GIS and remote sensing to study aquaculture development for watershed ponds in Thai Nguyen, Vietnam using Spot image and the study concluded that 4.7 per cent of the total land areas were suitable for watershed pond construction. The review above justified that GIS and remote sensing technology has encouraged aquaculture development in all part of the globe including Nigeria.

In addition, some researcher has carried out research in aquaculture and its important in different part of Nigeria. [20] Examined the role of woman in aquaculture development in Delta State Nigeria with 11.5 per cent of the total 2,533 fish farms owned by woman. The study also reveals that aquaculture production is estimated at 28,693.2 cubic tons per year in the state. [21] study the profitability of integrated fish cum crop farming and the effect of both socio-economic and demographic factors on farm income in Anambra state, Nigeria. Also, [22] in their work observed that a total revenue of N244364.30 k per cycle was realized with input of N129379.52 $\mathrm{k}$ per cycle in a study carried out in Sika-East LGA of Oyo State, Nigeria. [23] uses GIS to map fish farms in Anambra State and concluded that the highest concentration of fish farms is in Akwa North and South. In Andoni Local Government Area aquaculture site selection has not been carried out, especially with the integration of GIS and remote sensing technology. Hence, the objective of this study is to select suitable site for industrialize aquaculture pond development that will encourage direct and indirect jobs creation which will guaranty improved welfare of the population in term of food and income in the area using GIS software and remote sensing approach.

\section{METHODOLOGY}

\section{STUDY AREA}

The study area is Andoni Local Government Area, Rivers State, Nigeria and it lies between latitude $04^{\circ} 26^{\prime} 40^{\prime \prime} \mathrm{N}-04^{\circ} 35^{\prime} 00^{\prime \prime} \mathrm{N}$ and longitude $07^{\circ} 16^{\prime} 30^{\prime \prime} \mathrm{E}-07^{\circ} 33^{\prime} 00^{\prime} \mathrm{E}$. It has a total land 
mass of 342 square kilometres with a population 211,009 peoples [24]. The elevation varies from $0.0 \mathrm{~m}$ along the Rivers to $23.3 \mathrm{~m}$ in the upland area. The study area is bounded by Gokana and Khana LGAs in the north, Opobo/ Nkoro LGA in the east, Bonny LGA in the west, and South Atlantic Ocean occupied the whole southern part of the area. Being a coastal tribe of Niger Delta region the people are predominantly fishermen. The land mass is made-up off tributaries of Rivers, Creeks, and Lagoons of the main ocean which serves as fishing ground for the people to earn a living. The Rivers network support different species of aquatic fish especially the salt water species with most fishing activities being carried out in the marine and brackish water.

The following fish types are found within the mangrove of Niger Delta; mullets, Grunter, Snappers, Catfishes, Tilapia, Threadfins, Croakers, and shellfish such as Crustaceans, Molluscs [25]. [26] pointed out that Croaker, Baracuda, Skate Ray, Sharks, Snapper, Shinynose, Bonga, and Sole are the popular fish caught in Okwa Ibom State. The study area has a number of fishing settlements which include; Ibotokpong Obolo, Oyorokoto, Asaramaturu, and Mbalaka near Ataba town. Ibotokpong is located in the South-Eastern part while Oyorokoto, Asaramaturu, and Mbalaka and all the fishing settlement are located in the South-Western part of the study area. It is believed that Oyorokoto is the largest fishing settlement in the coast of West Africa. In general all Andoni towns and villages produced fishes in commercial quantities and for domestic consumption.

Fishing activities in the study area is carried out by different types of fishing gears (tackle) such as push net, stow net, traps, cast net, trawler, hook and line, and drag net. Trawler fishing is carried out in the open ocean usually resulted in large quantities of catch fish for sale in the market and reserved for consumption. In other to protect and preserved fish and other aquatic species, the local authority had place a restriction on the use of stupefying devices (chemicals or explosives) for fishing as it pollutes the water and resulted in excessive elimination of fish and other aquatic species. The extinction of fishes in the Andoni water over the years has discourage men and women, and the youths from engaging in fishing as profession with many youths indulges themselves in criminal activities. In Andoni Local Government Area there is no single aquaculture fish pond to complement gradual extinction of fishes and other aquatic species on one hand and to create job opportunities on the other hand in the area. This study will determine suitable site for the development of aquaculture fish pond that will create job opportunities by using data from remote sensing technology and GIS software to analyse the result. 


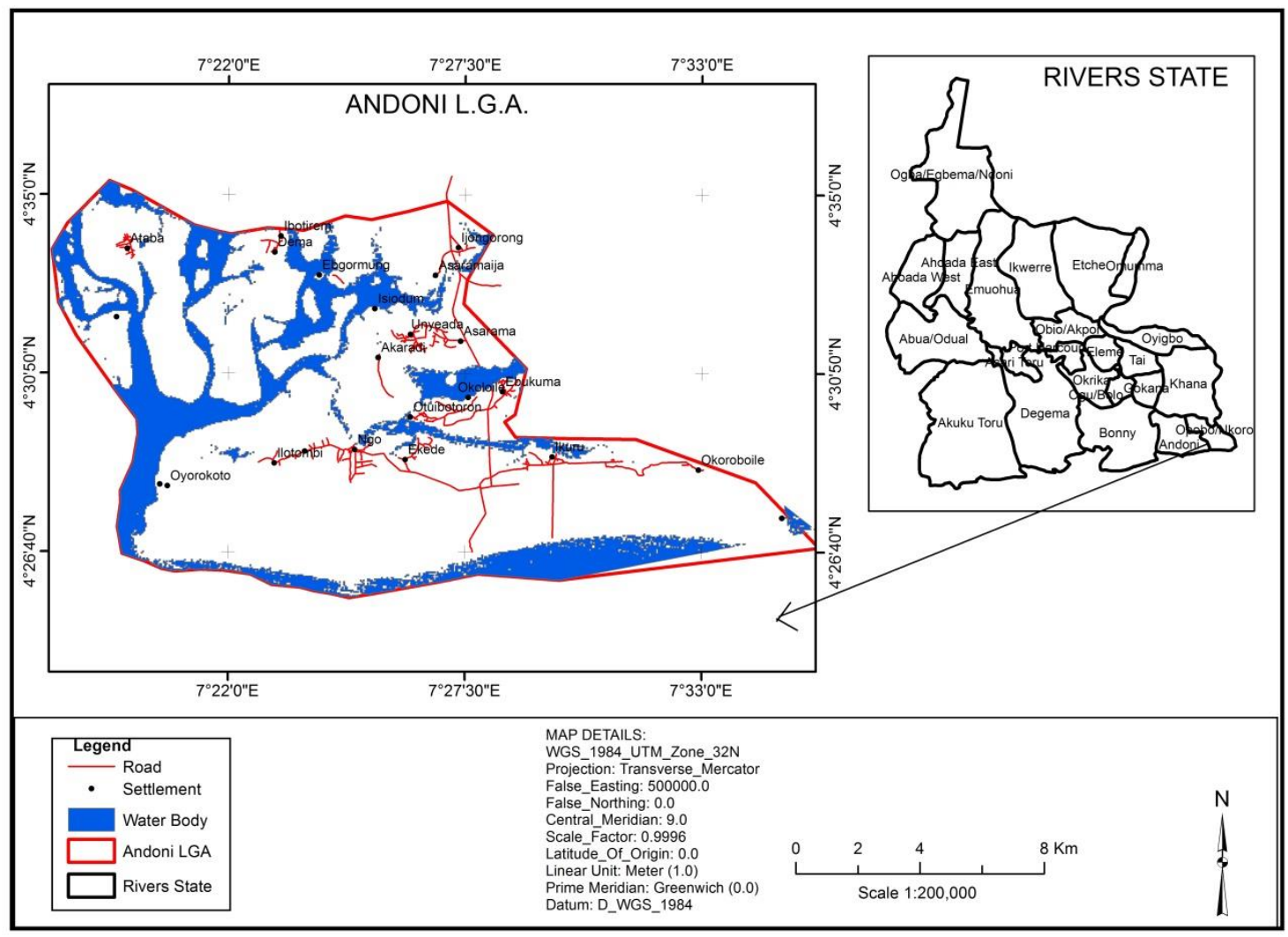

Figure 1: Study area map.

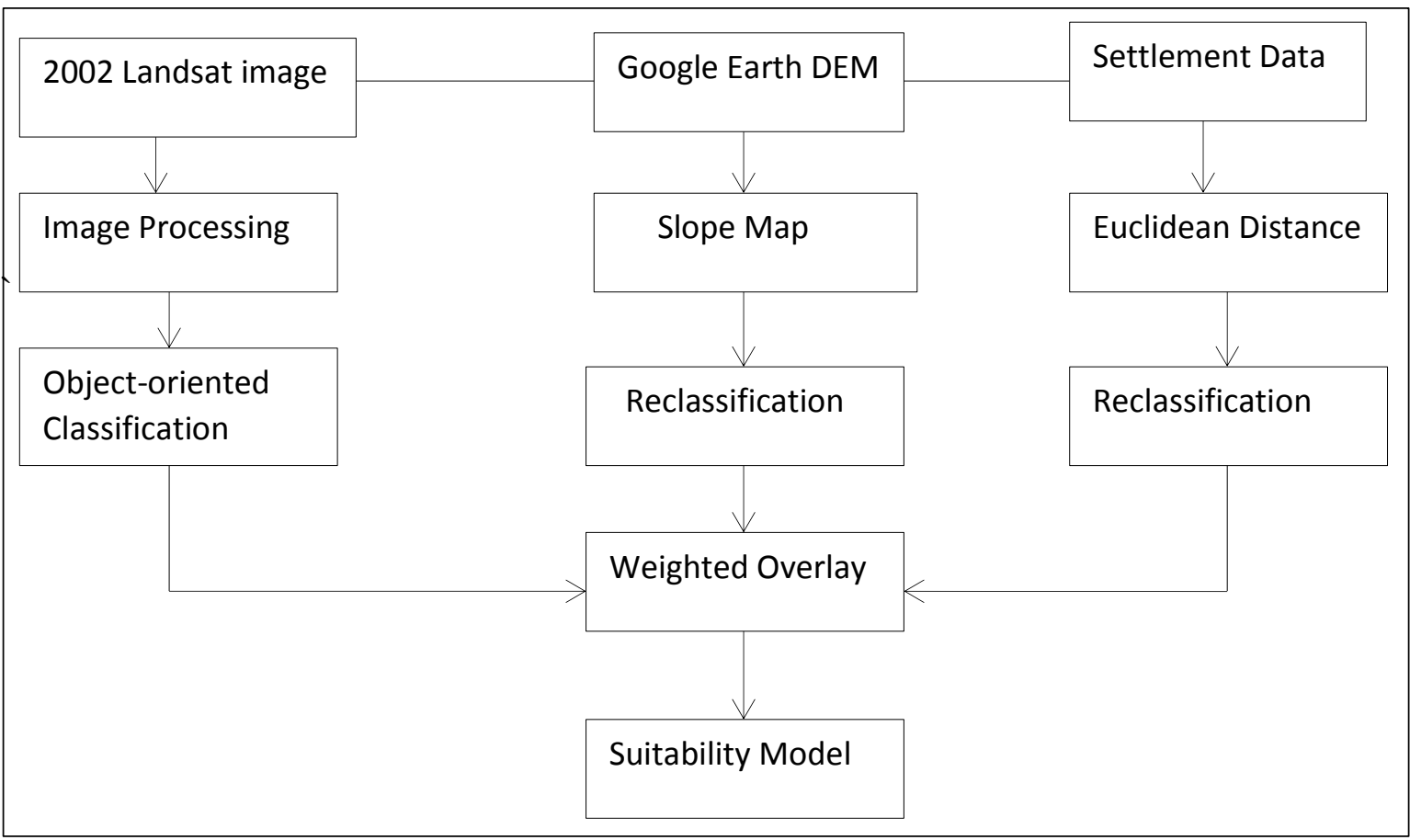

Figure 2: Flow chart methodology. 


\section{DATASET AND SOFTWARE}

Aquaculture fish pond development requires the selection of suitable site that will guaranty its optimal production. [27, 28] listed water availability and sources, soil characteristics, topography, flooding, draining, and pesticides as conditions to be considered for siting fish pond. But [10] categorized the various conditions into socio-economic and biophysical components. The dataset employed for the study is settlement data [14], DEM [13], and 2000 Landsat satellite image [12]. The digital elevation model (DEM) was extracted from Google Earth satellite image, because it has better accuracy compared to other sources of DEM [29, 30] except field observed DEM from conventional surveying methods as noted by [31]. The study utilized Landsat data of 2002 path 188 and row 56 with $28.5 \mathrm{~m} \times 28.5 \mathrm{~m}$ spatial resolution downloaded from its website (http://glovis.usgs.gov/). The Landsat image was needed to extract land use/ land cover of the area. The software used for the study is ESRI's ArcGIS 10.1 [15] for multi-criteria analysis and IDRISI TAIGA 16.0 for performing image classification.

\section{DATA PROCESSING}

\section{Image Classification}

The Landsat image was used to extract land use/ cover using object-oriented classification algorithms [32, 33, 34] in IDRISI software. Object- oriented classification was adopted because it allows each object (cover type) to be clearly trained during classification. The classification system adopted for lulc was level 1 according to [35]. The land use/ land cover types identified and classified in the study area are water body mostly salt water, built-up areas, Nypa palm, vegetation and sand dune. The total pixel per class in hectares of the lulc is shown in table 1.

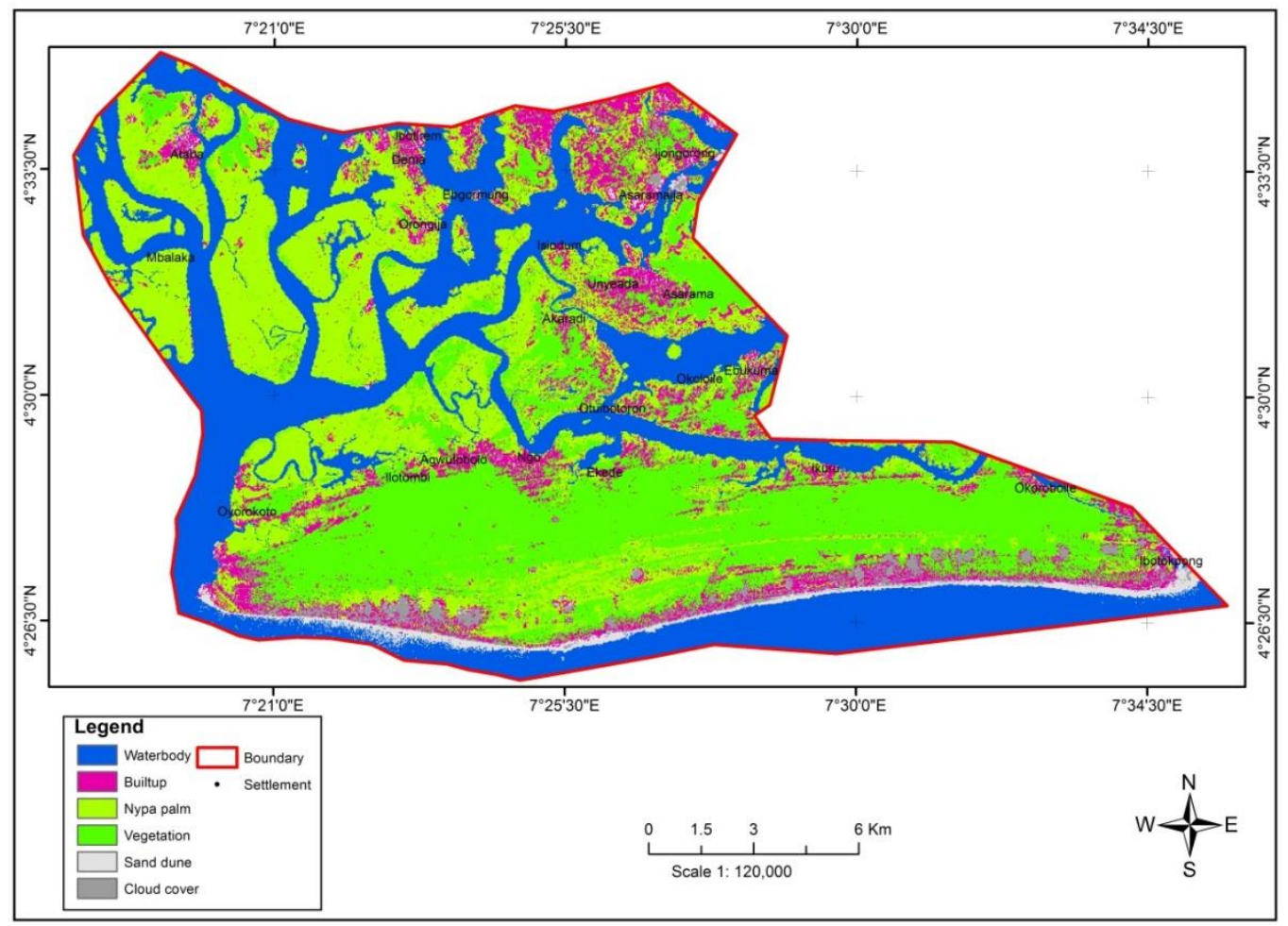

Figure 3: Land use / cover classification image. 
Table 1: Total pixel per lulc class in hectares from results of image classification.

\begin{tabular}{|l|l|}
\hline $\begin{array}{l}\text { LAND USE/ } \\
\text { COVER }\end{array}$ & AREA (HA.) \\
\hline Water body & 10186.75 \\
\hline Built-up area & 3405.76 \\
\hline Nypa palm & 9049.11 \\
\hline Vegetation & 8863.76 \\
\hline Sand dune & 629.01 \\
\hline Cloud cover & 793.89 \\
\hline Total & $\mathbf{3 2 9 2 8 . 2 8}$ \\
\hline
\end{tabular}

\section{Euclidean Distance}

The settlement data in the study area was used to performed Euclidean distance analysis from the spatial analyst tools in Arc GIS 10.1. Euclidean distance model is mostly applied in suitability analysis for selecting optimum site [36], and the module calculates straight line distance from every cell to a source cell. The operation was performed by imputing the source data (settlement point data) and the output file specified. For effective utilization of this data in weighted overlay analysis it was reclassified from the reclassify tool into ten (10) classes of equal interval. The ten classes were ranked and areas closer to settlement as least suitable with rank 1 while farthest distance from settlement as most suitable with rank 10. This condition applied because we want suitable site for aquaculture that will be away from settlements.

\section{Slope}

DEM generated from Google Earth image was imported into Arc GIS as point data in degree decimal for (lat, long.), and $\mathrm{Z}$ in meters coordinate. It was used to produce triangular irregular network (TIN) model and it was converted from TIN to raster model in 3D Analyst tools. The TIN to raster model was used to produce slope map in degree. The reclassify tool was used to reclass slope model into ten (10) classes of equal interval and the lowest angle of slope (0 - 0.294 degrees) rank 1 as least suitable areas and steepest angle of slope $(2.647-2.941$ degrees $)$ with rank 10 as most suitable areas. The lowest angle of slope occurs in the river and as such it was rank 1 since we don't want suitable aquaculture sites to be located in the river. Besides, all angle of slope will support aquaculture development since the angle of slope is not too steep. The output slope value in degree ranges from minimum 0 degree to maximum 2.941 degrees. 


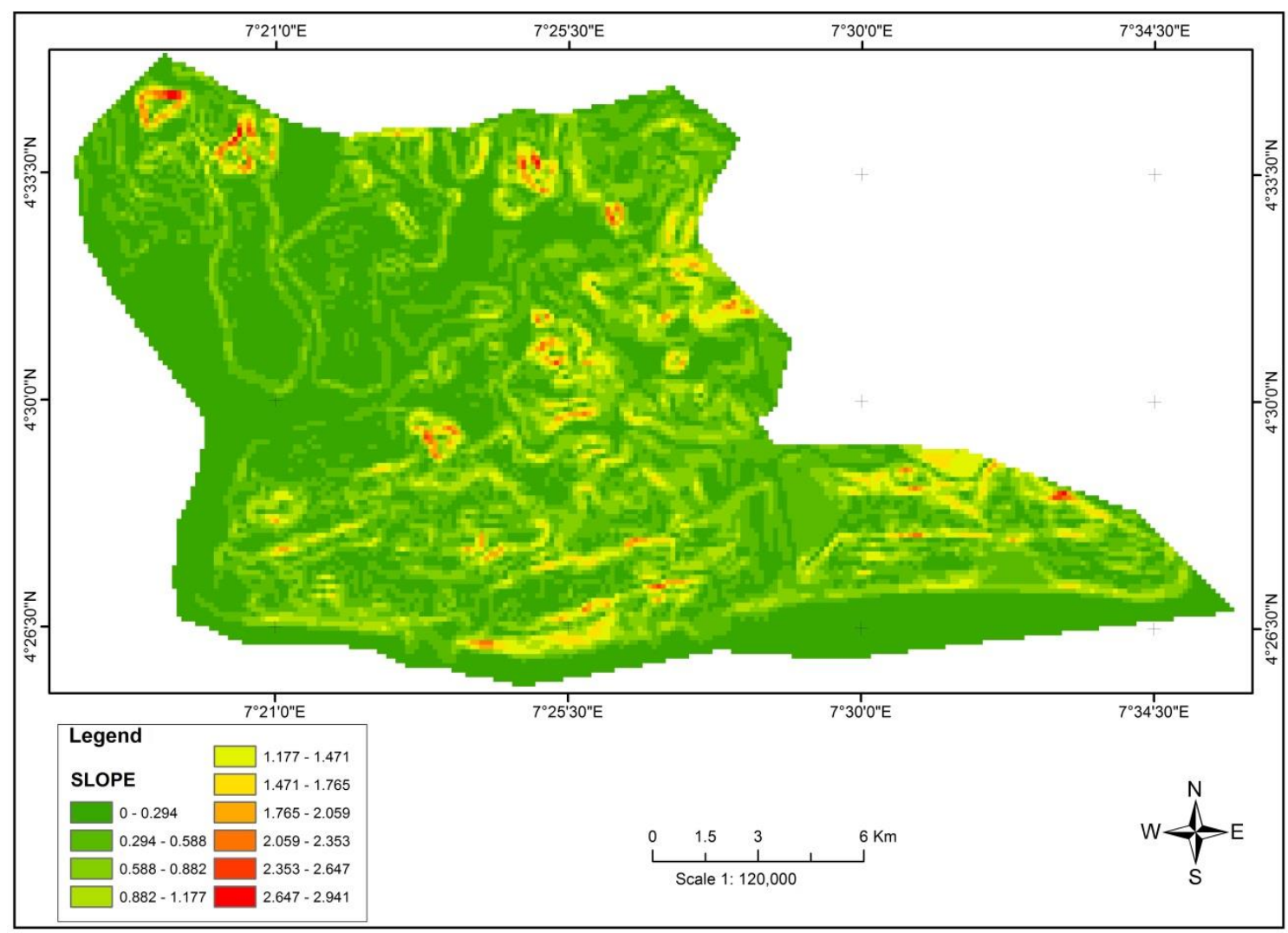

Figure 4: Slope model of the area.

\section{Weighted Overlay Analysis}

The three factors used in this weighted overlay analysis are land use/ cover, Euclidean distance from settlements, and slope map. Weighted overlay analysis enable factors to be combined and weighted to solve multi-decision problems in this case selecting suitable site for aquaculture. The three factors were loaded in the weighted overlay tool by setting the evaluation scale to 1 to 10 to 1 to agree with the reclassification of input to 10 equal interval classes. The land use/ cover were ranked with vegetation ranking 10 as the most suitable location for siting aquaculture. This was followed by Nypa palm, and sand dune ranking 9 and 7 respectively. Built-up areas were rank 2 as least suitable since we do not want aquaculture to be sited close to built-up areas. The water body was restricted in the analysis this is because aquaculture should not be located in the available water body as all water body sustained the local population with fishes and other aquatic species. The factors were assigned percentage of influence with Euclidean distance from settlements assigned 40 per cent, land use/ cover 40 per cent and slope 20 per cent. The suitability map was produced from the input as shown in the figure below. The conditional tool was used to extract each layer from 0 to 6 in the suitability model and the individual raster layers was converted to vector polygon using convert from raster to polygon command. Also, the polygon vector layers were converted to geodatabase so that the total area per class can be obtained. 


\section{RESULTS AND DISCUSSION}

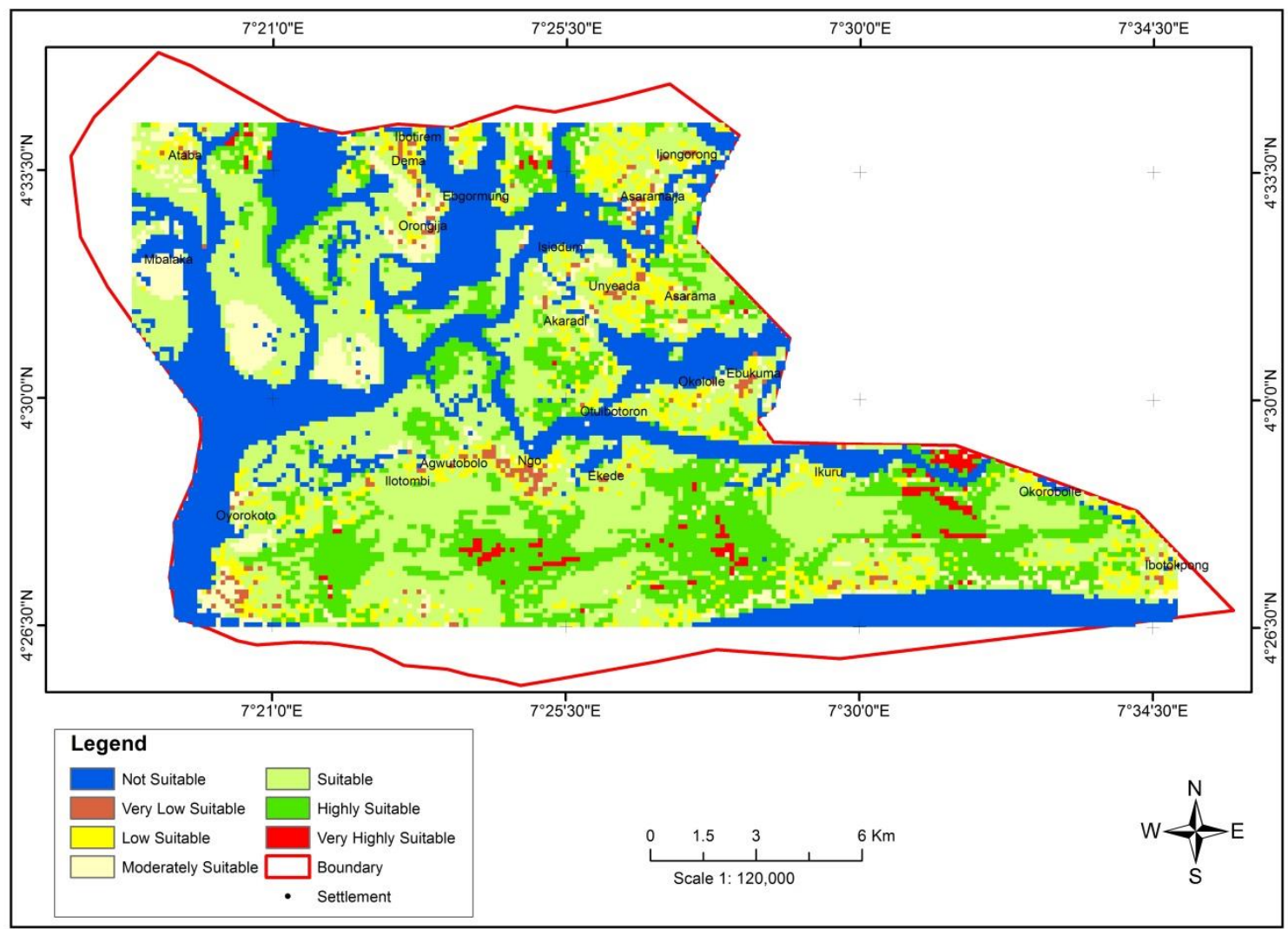

Figure 5: Aquaculture suitability map with seven (7) classes.

Table 2: Percentage suitability per class of the total area.

\begin{tabular}{|c|c|c|c|}
\hline $\begin{array}{l}\text { SUITABILITY } \\
\text { CLASS }\end{array}$ & CLASS NAME & $\begin{array}{|ll|}\text { TOTAL AREA } \\
\text { (HA.) }\end{array}$ & \% AREA \\
\hline 0 & Not Suitable & 8099.0 & 29.15 \\
\hline 1 & Very Low Suitable & 317.8 & 1.14 \\
\hline 2 & Low Suitable & 1822.0 & 6.56 \\
\hline 3 & Moderately Suitable & 1659.8 & 5.98 \\
\hline 4 & Suitable & 10499.1 & 37.79 \\
\hline 5 & Highly Suitable & 5104.8 & 18.38 \\
\hline 6 & Very Highly Suitable & 278.7 & 1.0 \\
\hline
\end{tabular}

The suitability model of aquaculture site selection analysis was shown in figure 5 above with seven different layers representing degree of suitability for it development. The suitability model was rank from the not suitable with class value 0 to very highly suitable with class value 6 . In the suitability model the red colour indicates very highly suitable aquaculture sites and these areas were located mostly in the vegetated areas. The very highly suitable areas were mostly clustered in the southern part of the study area which has the highest vegetation cover stretching from the Southern part of Ngo, Ekede, Ilotombi, and Ikuru to about 5 kilometers towards the Atlantic 
Ocean. Similarly, others very highly suitable areas were located close to the rivers in the southeast and northern part of the suability map. The location of these very suitable areas closer to water source [37, 38, 39, 40] is an added advantage for the development of aquaculture ponds because of the steady and consistence supply of water directly from its source. The very highly suitable areas in the southern region will support fresh water aquaculture ponds due to the distance from the salt water source from the rivers while those in the south - east and northern region of the study area will encourages salt water aquaculture ponds due to its proximity to salt water rivers. The very highly suitable areas cover a total area of $278.1 \mathrm{Ha}$., representing 1.0 per cent of the total area (32928.4 Ha.). It is made up of fifty one (51) polygons with maximum area of $50.3 \mathrm{Ha}$. and Minimum area of $1.2 \mathrm{Ha}$. The database was queried using select by attribute and eight (8) polygons have area greater than $10 \mathrm{Ha}$., thirteen (13) polygons have area greater than 5 Ha., and twenty two (22) polygons have area that is less than or equal to 2 Ha. However, aquaculture ponds size varies from place to place and from country to country. In Virginia ponds range in size from I acre $(0.41 \mathrm{Ha}$.) to 30 acres (12.14 Ha.) [39], also [41] suggested that cage ponds surface area from 1 acre $(0.41 \mathrm{Ha}$.) and above are ideal for aquaculture development. According to [42] the average crawfish pond size is between 50 to 60 acres (20.2 to $24.3 \mathrm{Ha}$.) but varies from country to country. In conclusion all the polygons representing class 6 (very highly suitable) in table 2 can support aquaculture ponds in the study area because 100 per cent of the polygons areas were within the above quoted pond sizes.

Above this class is the highly suitable region represented by quetzal green colour located more in the southern and little in the northern part of the map. These areas can equally support aquaculture development because it is located partly in vegetated, and nypa palm areas with adequate condition such as nearness to water supply and settlements that will provide business opportunities to the ponds. The areas covered a total land area of $5104.8 \mathrm{Ha}$. this represents 18.38 per cent of the total land area. Higher in the legend is another layer represented by lemongrass green colour considered suitable for fish farm, and these areas were located more in the southern part of the map and some on the available land in the northern region. The areal extent occupied by this layer is $10499.1 \mathrm{Ha}$. this represents 37.79 per cent of land area. The next class in the moderately suitable areas for fish farming that is located more in the north - west of the suitability map and part of north - east with few on the southern area. The total area is 1659.6 Ha. this represents 5.98 per cent of the study area. Higher in the legend is low suitable location for siting of aquaculture fish ponds and these areas were located in the built-up environment. The model considered built-up areas as not suitable because human activities will have impact on the pond thereby affecting its production. The area covered by low suitable site for fish farming is 1822.0 Ha. this represents 6.56 per cent of the entire area. The second to the last class considered very low suitable is located within built-up areas with a total area $317.8 \mathrm{Ha}$. and is 1.14 per cent of the total area. The last class considered not suitable for aquaculture ponds development occurs in the water body of the study area, this is because the water body was restricted in the analysis based on the fact that aquaculture cannot be sited in the water body as they provide the basic need of the people. It is the largest with an area of 8099.0 Ha. representing 29.15 per cent of the total land area as shown in lapis lazuli blue colour. Aquaculture development through the application of GIS software and remote sensing data will stimulate economic growth in the sector. 


\section{CONCLUSION}

The role of GIS which is a method of collecting, storing, management, analysing, and presentation of reports of geographically referenced data is gaining recognition in all fields including aquaculture. However, the application of it in aquaculture requires another technology called remote sensing (acquisition of data about the earth surface without any physical contact with the object being investigated through the use of sensors mounted on flat form) to achieve results. The synergy between these fields (GIS and remote sensing) is crucial to the study of aquaculture site selection at low cost and high level accuracy. This synergy is stabilized as GIS provides software needed to perform the analysis while remote sensing provides all the spatial data including images for the GIS. In this study, GIS and remote sensing technology was utilized to determined suitable site for aquaculture in Andoni LGA. The dataset used for the study are settlement, DEM, and land use/ cover derived from Landsat image. The data were processed and weighted using weighted overlay analysis in ArcGIS 10.1. The study observed that 278.1 Ha. of the land area was very highly suitable for aquaculture development this represent 1.0 per cent of the total land. Similarly, the total area considered not suitable for aquaculture site is $8099.0 \mathrm{Ha}$. and this represents 29.15 per cent of the land area. The establishment of aquaculture ponds will increase protein intake from the consumption of fish, eradicate youth's restiveness, provide employment opportunities, discourage oil theft and kidnapping, encourage socio-economic growth, and improved income level of fishermen. For further study it is recommended that the soil characteristics of the area be integrated into the analysis since soil formed important criteria for aquaculture site selection. Finally, the local government authority should integrate aquaculture into its programmes by either direct investment or granting of loans to individual that one to set-up the farm.

\section{ACKNOWLEDGEMENT}

It is a singular honour to God Almighty whose wisdom is freely given and translated to this work. We also thanks all those who red this work and made their comments to restructure the entire work. Finally, special appreciations to our wives who did not see our sleepless night as distraction but encourages the efforts in making this hard work a huge success.

\section{REFERENCES}

[1] Thompson O. A., and Mafimisebi T. E. Profitability of Selected Ventures in Catfish Aquaculture in Ondo State, Nigeria, Fish Aquac J, vol. 5, no. 2, http://dx.doi.org/10.4172/2150-3508.100096, 2014, 1 - 7.

[2] FAO. Food and Agricultural Organization of the United Nations, Fisheries and Aquaculture Development, 2016, 1 -2.

[3] FAO. Part 1 World Review of Fisheries and Aquaculture, the State of World Fisheries and Aquaculture 2014, Food and Agricultural Organisation of the United Nations, 2014, $1-6$.

[4] Green Economy and Trade. Fisheries and Aquaculture, 2013, 1 - 36, http://www.unep.org/greeneconomy/Portal/88/documents/ger/3.0_Fisheries.pdf. 
[5] FAO. The State of World Fisheries and Aquaculture 2010, FAO Fisheries and Aquaculture Department, Food and Agricultural Organisation of the United Nations, Rome, 2010, 21, http://www.fao.org/docrep/012/i1119t/i1119t.pdf.

[6] Badmus O., Jabil I. Y., Adedeji F. A., and Yacim S. E. Small Scale Aquaculture: A Panacea to Poverty Alleviation and Food Security in Alimosho Area, Lagos State Nigeria, Department of Agriculture Extension, Federal College of Animal Health \& Production, Jos Nigeria, 2013, 1 - 24.

[7] Michael S. Aquaculture - The Benefits of Aquaculture, 2014, http://fishery.about.com/od/BenefitsofAquaculture/a/AquacultureBenefits.htm.

[8] Oluwasola O., and Ajayi D. Socio-Economic and Policy Issues Determining Sustainable Fish Farming in Nigeria, African Journal of Agriculture Economics and Rural Development, Vol. 1, No. 1, 2012, $035-041$.

[9] James M. K., and Jose A. M. Geographic Information Systems, Remote Sensing and Mapping for the Development and Management of Marine Aquaculture, FAO Fisheries Technical Paper 458, 2007, 11 - 100.

[10] Shree S. N., John P. B., Lindsay G. R., and Jose A. M. Application of Geographic Information Systems (GIS) for Spatial Decision Support in Aquaculture, Aquaculture Engineering Vol. 23 (2000), 1999, 233 - 278.

[11] Dao H. G., Yang Y., and Amararatne Y. GIS for Evaluation for Shrimp Farming in Haiphong of Vietnam, Ocean and Coastal Management, Vol. 48, Issue 1, 2005, 51 - 63.

[12] Shen L. GIS-Based Multi-criteria Analysis for Aquaculture Site Selection, Dr. Bin J. Examiner, Dr. Anders B. Supervisor, Department of Industrial Development, IT and Land Management, University of Gavle, 2010, 1 - 51.

[13] Zainul H. Application of GIS for Assessing Prawn Farm Development in Tully-Cardwell, North Queensland, Jurnal KELAUTAN Vol. 4, No. 2, 2011, 62 - 67.

[14] Raj C., and Karuppasamy S. Marine Fishery Information System and Aquaculture Site Selection Using Remote Sensing and GIS, International Journal of Advanced Remote Sensing and GIS, Vol. 1, Issue 1, ISSN 2320-0243, 2012, 20-33.

[15] Raushan K. R., and Nikunj B. G. Study on Potential Application of Geographic Information Systems (GIS) to Find Out Suitable Aquaculture Site in Pune - Maharashtra India, International Journal of Advanced Remote Sensing and GIS, Vol. 3, Issue 1, (2014, $669-680$.

[16] Simms A. GIS and Aquaculture: Assessment of Soft-Shell Clam Sites, Journal of Coastal Conservation, Vol. 8, 2002, 35 - 47.

[17] Buitrago J., Rada M., Hernandez H., and Buitrago E. A Single-use Site Selection Technique, Using GIS, for Aquaculture Planning: Choosing Locations for Mangrove Oyster Raft Culture in Margarita Island, Venezuela, Environmental Management, Vol. 35, No. 5, 2005, $544-556$.

[18] Longdill P. C., Healy T. R., and Black K. P. An Intergrated GIS Approach for Sustainable Aquaculture Management Area Site Selection, Ocean \& Coastal Management, Vol. 51, No. 8, 2008, 612 - 624.

[19] Giap D. H., Yi Y., Cuong N. X., Luu L. T., Diana J. S., and Lin C. K.. Application of GIS and Remote Sensing for Assessing Watershed Ponds for Aquaculture Development in Thai Nguyen, Vietnam, In Map Asia 2003 Conference, 2003.

[20] Nwabueze A. A. The Role of Woman in Sustainable Aquaculture Development in Delta State, Journal of Sustainable Development in Africa, Vol 12, No. 5, 2010, $284-293$. 
[21] Uqwunba C. O. A. Environmental Sustainability and Profitability of Integrated Fish Cum Crop Farming in Anambra State, Nigeria, Agricultural Journal, Vol. 5, No. 3, 2010, 229 $-233$.

[22] Adeniyi B. T., Kuton M. P., Ayegbokiki A. O., and Lawal H. O. Economic Analysis of Costs and Return of Fish Farming in Sika-East Local Government Area of Oyo State, Nigeria, Aquac Res Development, Vol. 6, No. 2, 2015, 1 -5, http://dx.doi.org/10.4172/2155-9546.1000306.

[23] Ojiako J. C. , Okafor C. M., and Igbokwe E. C. Geospatial Mapping of Fish Farms in Anambra State Using GIS Approach, International Journal of Scientific \& Engineering Research, Vol. 6, Issue, 11, 2015, 42 - 53.

[24] National Bureau of Statistics, "Official Gazette (FGP 71/52007/2500 OL24), National and State Provisional Total 2006 Census, ” 2006.

[25] Isebor C. E., Ajayi T. O., and Anyanwu A. The Incidence of Nypa Fruticans (Wurmb) and it's Impact on Fisheries Production in the Nger Delta Mangrove Ecosystem, Nigerian Institute for Oceanography and Marine Research, Victoria Island Lagos, Nigeria, 2003, 1- 4.

[26] Imaobong E. E., and Mandu A. E. Development, Prospects and Challenges of Artisanal Fisheries in Akwa Ibom State, Nigeria, International Journal of Environmental Science, Management and Engineering Research, Vol 2, No. 3, 2013, 68 - 86.

[27] Thomas L. W. Site Selection of Levee-Type Fish Production Ponds, Southern Regional Aquaculture Center, SRAC Production No. 100, 1988, 1 - 2.

[28] James T. D. Red Drum Site Selection and Pond Construction, Southern Regional Aquaculture Center, SRAC Production No. 321, 1990, 1 - 4.

[29] Hoffmann E. Generating High-Resolution Digital Elevation Models for Wetland Research Using Google Earth (TM) Imagery- an Example from South Africa, water, 2010, 1-24.

[30] Sadeg H. A. Accuracy Evaluation of SRTM (use in Google Earth) by Comparison with National Topographic Map (1:50,000) in North of Iraq, Eng. \& Tech. Journal, Vol. 28, No. 21, 2010, 1-10.

[31] Heywood I., Cornelius S., and Carver S. An Introduction to Geographic Information System, 3rd Edition, Pearson Education Limited, Edinburgh Gate Harlow Essex CM20 2JE England, 2006, 77 - 91.

[32] Richard J. U. Object-Oriented Classification Using Aerial Photograph and Spot Image of Eagle Island Port Harcourt, Rivers State, Nigeria, International Journal of Advance Research, IJOAR .ORG, Vol. 3, Issue 12, December 2015, Online: ISSN 2320-9186, 2015, $11-23$.

[33] Lucky C. C. Object-Oriented Image Classification of Individual Tree Using Erdas Imagine Objective: Case Study of Wanjohi Area, Lake Naivasha Basin, Proceedings, Kenya Geothermal Conference 2011, Kenyatta International Conference Centre Nairobi, November 21-22, 2011, 2011, 1 - 9.

[34] Li F., Jian C., and Yongheng Z. Object-Oriented Classification of High-Resolution Remotely Sensed Imagery, International Conference on Computer Technology and Science (ICCTS), IPCSIT vol. 47, LACSIT Press, Singapore, DOI: 10.7763/IPCSIT.2012. V47.76, 2012, $411-416$.

[35] Anderson J. R., Ernest E. H., John T. R., and Richard E. W. A Land Use and Land Cover Classification System for Use With Remote Sensor Data, Geological Survey Professional 
Paper 964, A Revision of the Land Use Classification System as Presented in U.S. Geological Survey Circular 671, 1976, 1 - 41.

[36] Khalid E. Developing a GIS-Based MCE Site Selection Tool in ArcGIS using COM Technology, the International Arab Journal of Information Technology, Vol. 10, No. 3, (2013, $1-7$.

[37] Jimmy L. A. Site Selection of Levee-Type Fish Production Ponds, Southern Regional Aquaculture Center, SRAC Publication No. 100, 2010, 1 - 8.

[38] John W. J. Watershed Fish Production Ponds Site Selection and Construction, Texas Agricultural Extension Service, Southern Regional Aquaculture Center, SRAC Publication No. 102, 1989, 1 - 4.

[39] Louis A. H., and Garland B. P. Pond Construction: Some Practical Considerations, Wirginia Cooperative Extension, Fisheries and Wildlife, Publication 420-011, 1997, 1 4.

[40] Gregory N. W. Watershed Fish Production Ponds Guide to Site Selection and Construction, Southern Regional Aquaculture Center, SRAC Publication No. 102, 2002, $1-6$.

[41] Michael P. M. Cage Culture Site Selection and Water Quality, Southern Regional Aquaculture Center, SRAC Publication No. 161, 1997, 1 - 4.

[42] Larry W. B. and Robert P. R. Crawfish Culture Site Selection, Pond Construction and Water Quality, Southern Regional Aquaculture Center, SRAC Publication No. 240, 1990, $1-4$. 